\title{
Teresa Bruś*
}

"but still ... dots intervene."

Virginia Woolf

\section{Becoming Dislimned \\ Zones of Ellipsis in the Essays of Brian Dillon}

DOI: http://dx.doi.org/10.12775/LC.2020.040

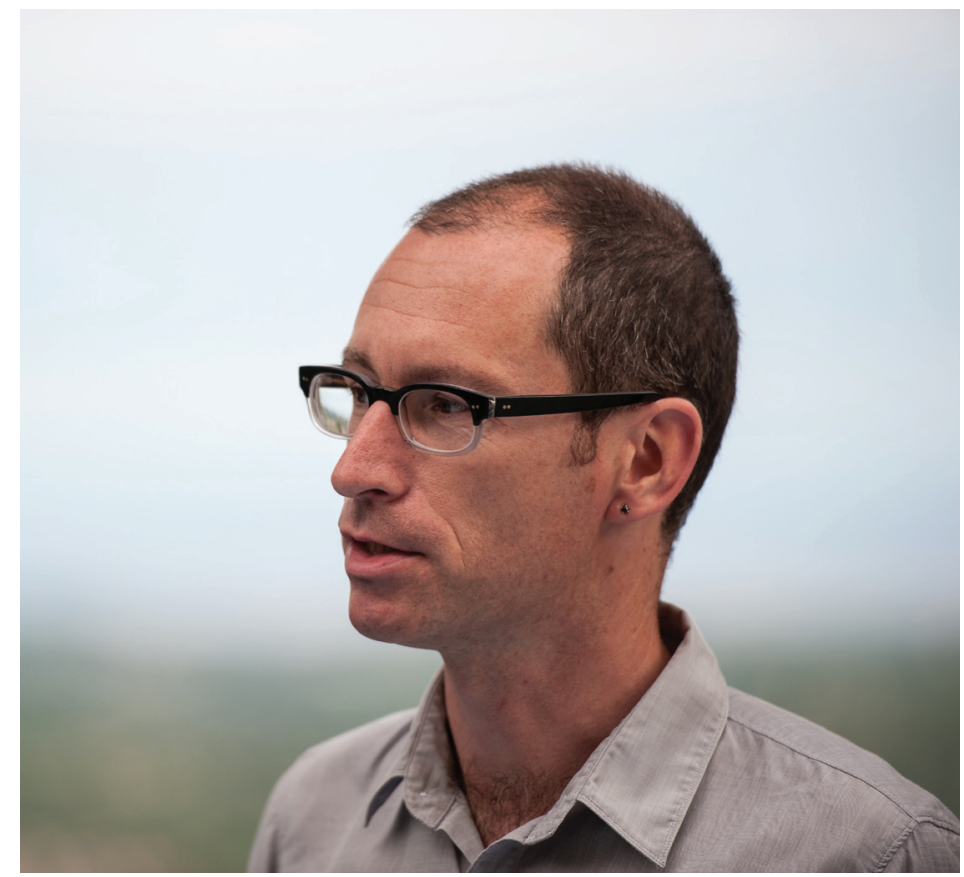

(C) Chris Dixon. Reproduced by kind permission of Brian Dillon

* Dr hab., Associate Professor at the University of Wrocław. Her major fields of research include visual culture, photography and literature, and life writing.

E-mail: teresa.brus@uwr.edu.pl |ORCID: 0000-0003-2845-7195. 
llipsis is not a uniform phenomenon. Its options are diverse: an interruption, reduction, omission, deletion, elimination, gap or lack. Ellipsis (élleipsis), etymologically, conveys "lack" - from elleípō meaning "I neglect", "suspend", "omit" and, from leípō to "leave behind", "to leave out" (Suszek 2019: 159). Marked since the $16^{\text {th }} \mathrm{c}$ by a silent string of periods or full stops, this apparent form of economy, of "brevitas", can create intelligent surprises and suspense (Lausberg 2002), suggesting an infinitude of associations. Rhetorical, geometric, and metaphoric ellipses introduce a deaccenting capable of amplifying their salient contents. As a caesura or hiatus, ellipsis appears as a textual state operating within the interior of a text. By omitting important elements, it both eludes and emancipates identity of objects. Through disconnecting, it also invites tightening. This is especially the case of metaphoric ellipses operating, as Agata Stankowska proposes, in an interpretative poetic space as a "field of semantic gravitation between fragments of texts distanced through 'suspension" (2001: 127). In such a field "lack" evokes a "field of semantic tension and relations between: a word and a word, an image and image, author and reader, and, finally, between expressed senses and the fullness of the act of contemplation and creation of reality in its new boundaries - a field that escapes verbal expression" (ibid., translation mine). Activated by a reader, the unapparent ellipsis opens up the singular vision of the world of the author and his/her aesthetic commitments. Considering Brian Dillon's essays, I will demonstrate how a special metaphoric case of ellipsis discloses a writing strategy of a man of experience.

The Irish writer and critic Brian Dillon is a varied essayist. Probing essays, Dillon launches a wide range of ideas on photography, the body, literature, memory, places and ruins. In the Dark Room, his first book, was published in 2005 and won the Irish Book Award for non-fiction. Essayism, published in 2017, brought deserved acclaim of readers. In books of criticism and life writing, Dillon always expects things to fall apart. But it is in the essays where subtle ellipses and interruptions bring consolation and even hope.

Ellipsis establishes a close relationship with silence and, in Max Picard's words, its ways of keeping things "inviolate from contact with language" (1952: 63). Working per detractionem, it coordinates elements of communication that cannot be accommodated in relations of subordination. We can discern its workings in literary forms which set out to probe strategies of self-determinacy where dissolution is a force field explored by a selfdetermined figure to expose his vision of the world. Thomas De Quincey, for example, uses the aerial verb "to dislimn", the verb coined by Shakespeare, to describe a process of the loss of "lineaments by stealthy steps" (1922: 28). He writes about his personal experience when as a tourist he came to "launch himself on the boundless ocean of London" (ibid.: 140) and like a cloud became dislimned. De Quincey often thinks in elliptical terms, moving through discursive gaps and fissures. Anatomizing clouds, the contemporary Irish essayist Brian Dillon, regarding his melancholic persona and his "depleted essence", also recovers figures of perforation. Himself a "kind of cloud", he feels he can "dissolve completely, to become the airborne spectre of himself" (2006: 27). Essayists tend to suspend postulations of totality, opting for a discontinuous path, an "unmethodical method" (Kauffmann 1989), illuminating openness, loss of thickness of reality and security in their own identity. On this path, leaving out, ellipsis, becomes a means of expressing both the unknown as well as something 
understood. An essayist may intervene to gravitate his attention towards the reader; by dislimning, by obliterating contours and leaving out elements, he may be actually tightening relationships and illuminating (limning) connections.

Probing the significance of elliptical rehearsals of limits of insight into the self in personal essays by Brian Dillon from his volume Essayism (2017), as well as his collection In the Dark Room (2005), we confront repetitive turns to personal losses. They amplify central truths about the subject, his overwhelming grief and silence, and struggles with their articulation. The essay as a form resists totalizing habits of thinking, hence its hesitations, interruptions, and omissions. Adorno's well-known emphasis that it "erects no scaffolding and no structure" (1999: 13) highlights the essay's "differentiatedness" (ibid.: 15). Its way of "thinking in and through breaks" (ibid.: 16) depends on lapses of connectivity and regularity. Thus, turning away from exactness, "abrogating certitude" (ibid.: 13), the essay renders wholeness and presence as always contingent. Dillon isolates Adorno's fragmentary impulses to remind himself that a "writer should never begrudge deletions" as long as he remembers to express what he wants to express (2017: 71). Dillon follows this recommendation.

Dillon's bodied essayistic experiments are set to recognize and communicate limits of his self-knowledge. His intermittent essayistic "I", addressing the chaos of selves produced by his diseases, vulnerability, and weaknesses, records various stages of the processes of fading away. The body and the bodily that Plato and Aristotle considered a "deterrence to clear thought" (Dolmage 2009: 2), under the essayistic examination of words and other bodies, emerge not emptied of meaning but essayed. Montaigne, in Auden's words, was the first "to give / The Flesh its weapons to defeat the Book" (1991: 301). Woolf chose the personal essay to show that of the "daily drama of the body there is no record" (2010: 195) and that "Those great wars which the body wages with the mind a slave to it, in the solitude of the bedroom ... are neglected" (ibid.: 196). The ill body not only changes; it "smashes itself into smithereens" and such developments, as Woolf knew too well, defy the existing powers of language. Essayists who try to utter the unspeakable personal disaster face the need of creating new languages and new hierarchies (ibid.: 196). The experience of the body, "the confused and confusing, broken, bodied" capital (Dolmage 2009: 4) calls up not a discursive but a bodily type of intelligence, which may be identified as mêtis. By engaging with contexts elliptical and shifting in Dillon's essays, we can reclaim this forgotten classical figure.

The personal essay is an appropriate arena for mêtis, the intuitive, cunning, adaptive, and embodied intelligence, a way of knowing. The word mêtis in fact means wise and witty intelligence. In the classical world the word "shared an association ... with the idea of a physical curve, with the idea of a body not composed in perfect ration" (Dolmage 2009: 7). The word is associated with the Greek goddess Metis named to be identified with this intelligence, connecting power of the body with knowledge. It is not systematic or rational, and in fact mêtis "never goes forward in a straight line but is always weaving from side to side and looping back on itself" (qtd. in Dolmage 2009: 6), changing and distorting contexts. Thinking about suffering readers, Woolf notices how the ill body "makes us disinclined for the long campaigns that prose exacts" (2010: 201). When attention fails, when the body makes its failing presence too painful, we do not fare well in a linear progress of rational thought. Instead, in Woolf's words, we lag, and drag, and stray, leaving many things out. Aligning 
the body with the unmethodical method of the essay, and the essay with the failing body, disintegrating body, also gesturing to other failing and failed bodies, we discover expressive possibilities of lack and omission. In Dillon's essays, the elusive "I", the mêtis, engages obsessively in corporeal thinking occurring through disarray and gaps.

In Cunning Intelligence in Greek Culture and Society (1991) Marcelle Detienne and Jean-Pierre Vernant present mêtis, a non-discursive knowledge of the body, as an unnamed mode of cognition, a type of thought, and an embodied rhetoric occurring in a specific context. Mêtis has been devalued in modern culture but we can find its cunning presence and its resourceful role in the form and attitude which the founder of the essay, Montagne, associated with ignorance forte et généreuse. Major features of the modern essay such as pliability, looseness and polymorphism, applied to transient and ambiguous situations and attitudes, are also those of mêtis. Individuals (and animals) gain mêtis by participation; they are endowed with it by experience. Transitory, unstructured, and anchored in the body, perceived often as naïve cognition, mêtis merits attention also as a carrier of unexpected ellipses.

Brian Dillon is an intensely personal non-fictioneer, one who identifies himself as "the depressive Irish writer" possessed by an interest in the all-defining "structure of doubt" he shares with other melancholics (2017: 128). Like Woolf, he is concerned with the paucity of language, with the always threatening event of depletion of figures and words with which to control fear, with which he could support his frail, decaying, failing, and disappearing "I". Dolmage is attentive to the pun in the Greek me and tis meaning "no man" or "no one", and mêtis as a "person whose identity can be elusive, who is unpredictable but resourceful and clever" (2009:5). Dillon, feeling like a disappearing entity, examines his essayistic self as it is transforming "to sand and spray" (2017: 66), disintegrating, diminishing, and losing metaphors for the future. Writing, "real writing" ceases, becomes suspended when the "Bad Thing", his depression, interrupts (2017: 128). Inability to write, the painful caesura, his most extreme debility appears too frequently. Dillon discloses: "I lived, as it were, at the extremity of my own body" (2018: 205), "on the surface of the body" (2018: 199). A large span of his life happens and develops as the body. Yet when the "Bad Thing" is lifted, writing resumes to invoke that body in the most subtle and intensely personal ways. Mètis "calls on changing opinions and positions" (Dolmage 2009: 10) and Dillon employs them to articulate what transgresses the boundaries of the essayistic personal.

Dillon's ellipses operate in dark rooms. When he miraculously manages to peek away from them into a camera lucida, he recalls ellipses and their overbearing grip on him. The gravitational force between these two rooms is bound not only with metaphors of light but also with an emerging vision of a creative process. To flow, his writing requires the memory of "the dark geometry of recollected and still keen grief" (Dillon 2018: 49), his own memories and those of writers like De Quincey, who recalled and tested his grief and pain also in relation to spaces. Dillon develops the image of his space like a photograph, carefully exposing its negative to light. A renewed attention to constellations of metaphors for elimination and loss expose the texture of his pain. Such metaphors are constitutive for the writing subject and vital for the recreation of his world. At the same time the metaphoric ellipsis of the dark room works to illuminate a special kind of creative excess. What is important is the fact that he does make it connect with light. Its memory always commands consolation. The sense of ellipsis resides not in words, Stankowska argues, but "beyond 
them". Confronted with the ellipses, we must turn to "what is not there" and "activate" it (2001: 128). Dillon does so by turning to the bodies in diverse rooms of memory "which are nonetheless connected" (2018: 50) and by trying to piece tiny elements - relics of his vulnerable childhood and its lights - together.

Stankowska also argues that unlike any other figure, ellipsis is a "being in interpretative space" operating in the space of poetics stretching between the unverbalized semiotic gesture of the author and the multiple attempts to verbalize these gestures undertaken by the reader (2001: 128). At stake in this motion is the subject and the vision of their participation in the world (ibid.: 128). Dillon reaches for ellipsis to test his hold on living as writing and remembering. Attending to ellipses in his essays, we attend to the essay as a form, provoked with the openness and adventurousness of his revelations beyond their conventional constellations.

In his very restless and very anxious perambulations, Dillon adopts the essay as a mode of an experiment, in attention to an omnium-gatherum composed from his findings and his readings. In Essayism, published in 2017 and described by Wayne Koestenbaum as a "moving and vulnerable love letter to the essay as a genre" (2019: n.p.), he explores lines of connections and omissions this itinerant open form presents. The essay "can be made up of fragments", itself being a fragment (Dillon 2017: 68), or a relation of the fragment (ibid.: 71). Sharing "ambiguous shuttle between identity and dispersal, between formal, almost physical integrity and a fracturing or even pulverizing action" (ibid.: 68), the essay rests on deliberate interplay of disparates and particulars. It catches splinters and fragments, sprawls and dispersals, "all airborne things" (ibid.: 72), "all manner of heterogenous matter" (ibid.: 72), revealing other fields of fragments. In such conglomerate spaces, constellations of fragments abut one another, writes Dillon. His attention is swayed not so much towards unity, rhythm, and exactitude, but in the direction of evasion, of "the simultaneous struggle and agreement between fragments" (ibid. : 72), be it in paratactical arrangements or those resting on contention as in an argument, or style. The "struggle and agreement" of forces can be achieved when an element (such as a productive or provocative metaphor) is found to capture the force at work in a text or object under discussion. Once found, it is "deployed with certain lightness, pushed as far as it will go and then given up" (ibid.: 105-106). Such orchestration of ellipses opens up visions of hope.

For Dillon, the enclosed entity, the essay, aspires to dispersal while being formed. Its dutiful links left out, its "sidelong glance, obliquities and digressions" hint at what he isolates as "mute truths" (ibid.: 12). Hence, the essay's distinctive regard for "punctuation marks, their meaning and morality" (Dillon 2017: 12). This established mode of thought figures the page as "an estuary, dotted at intervals with typographical buoys and markers" (ibid.: 12-13). Ellipses become meaningful when they attract heterogenous things but also redirect movement.

Dillon says the essay "invariably departs from the objects at hand to enter realms of speculation and even fantasy, because that is the liberty that such attention allows" (2017: 123). He praises the resulting consoling effect of the essay - its accordance with fragmentation. Agreeing with Francis Bacon, who argued that in the essay "the discourse of connection and order is cut off” (ibid.: 17), he embarks on his essayistic weighing of personal experience of carnal obsessions and failures, experiences splaying and dissecting his time and course of life. 
In Essayism Dillon not only credits the essay with the power to change things, change him (ibid.: 129), and the power to console but he also exercises its unique mode of intense attending, obliquely, "to one strand of existence" (ibid.: 121). The essay, an art among arts, sustains "coolness and simplicity" (ibid.: 133) as well as various types of emotional, intellectual, and aesthetic complexity (ibid.: 134); it is the only writing, he always stresses, that he was capable of when struck by debility. The question of whether it was possible to "write out of the fog itself, out of confusion, disarray, debility? From inside the disaster itself?" (ibid.: 120) is answered when he reveals that in his youth he felt himself to be a "broken product of mental and bodily sickness" and that writing indeed saved him (ibid.: 93). Unable to "connect nothing with nothing" (ibid.: 63), he kept on writing his fracturing and pulverizing essays. He created conglomerates, elliptical pieces.

It should be mentioned that Dillon speaks of the essay but also relies on "essayism" to identify a practice, an attitude to the form - "to its spirit of adventure and its unfinished nature - and towards much else" (ibid.: 20). Essayism then is "a habit of thinking, writing and living that has definite boundaries" (ibid.: 20-21). This attitude to writing, provided you loved something intensely enough, he says, could "uncover whole new worlds of tone and thought" (ibid.: 89).

His In the Dark Room, published in 2005, won the Irish Book Award for non-fiction. It is a meditation on mourning, an essay full of bodily adventures; his mother's ill and dead body and his own almost always out-of-control body. Here Dillon writes about his dead mother's face looked at - for the last time during a dreadful and unexpected "viewing" event in a mortuary of a Dublin hospital in July in 1985. He was sixteen and this traumatic experience became eventually only an adjacent image to a memory that he does not have - the memory of his mother's death. Thinking of this absence, he asserts only fragments of experience - adjacent images and patches of light. He recollects her face, giving the appearance of sleeping. He remembers one point of light "condensed around a being who has become, in fact only a face" (2018: 171-172). We are reminded of Roland Barthes's recognition of the significance of such a light as a "kind of mediation" which, when searching for the true image of his mother, he writes, led him "toward an essential identity, the genius of the beloved face" (1993: 66). Dillon cannot remember his mother's corpse: "we gathered not around the body but before a face. The face is perhaps as much of a reminder as we can bear" (2018: 172). Feeling awkward in front of the body, matter that "seems a reminder only of my distance from my mother's death" (ibid.: 176), he notes his gaze fracturing, his thoughts upon the sad ritual served only to fix the moment in memory - discomposing. Also luring the mind into a comment on his mother returning from the funeral of an aunt about the deceased woman's face looking much younger after her death. The memory of the mention of this rejuvenated face recalls in turn memories of Proust's grandmother's beautiful face in one of her photographs and her dead face which Marcel did not see, noting instead the imaged face. Dillon concludes that the face of the deceased moves us into the unknown: it both "drags us" into the past and "shoves us forward" into some future (ibid.: 174). It is an ellipsis. He returns to the last glimpse of the face, when before the closing of the coffin his grandfather tries hard to wave a fly away from her cheek. This and the other "cracked" images confirm his misrecognition. They sever his body not only from the body of his mother but also from other bodies. Bodies lose solidity for him: "The corpse, a reminder of the living body, returns us to our remembering body. Together they make 
a frieze that is subject to the violent amputations of forgetting and the aching reminder of bodies long gone" (ibid.: 177). Yet, absent, they can connect.

Scleroderma, before it killed his mother, destroyed her face by tightening and altering its shape until the face became alien, Mauskopf, a mask: "lips, nose, eyelids and cheeks all lose their mobility" (ibid.: 184). Impassive, it became relaxed and permanently scarred in the most advanced stages of the disease. Skin, and attention to skin, he says, is what defined his life. His own skin condition - psoriasis - not only marked his adolescence but with time assumed a mirroring function. His "epidermal map of woe" marks "an uninterrupted blizzard of dead skin drifting from my raw, red scalp" (ibid.: 201). So profuse was it that he felt himself "vanishing in blizzards of my skin as I tried to shake away the peelings of my pain” (ibid.: 200). This is a particularly evocative image of dispersal. Particles of skin, like elliptical specks in the sprawling field of life, become nevertheless contained and connected with other life fragments. "Adrift in ash debris", he anticipated the worst, speculating and fantasizing about his inevitable collapse. An intense decade dedicated to concentration on the condition, he admits, taught him "a lesson about the intimacy of the body, memory and unacknowledged loss" (ibid.: 203). Most of all, what years later he assesses as the "adventure of my skin" was also an experience of affinity: "all my unspoken fears about my mother's illness had arisen to the surface of my own body, there to compose a legible alphabet of expressive fissures and contusions" (ibid.: 206). He testifies to his progress despite and with ellipses. This was the alphabet he used in the last years of his mother's illness to "signal across the space between us all that I could not express in words". It worked to make him feel closer to her. When she died, he confesses: "I still carried with me, written on my cracked, peeling scalp, a relic of her pain" (ibid.: 206). By shifting attention to his body he manages to connect with her. By writing, he allows himself to suspend and to move on. Dillon thus works through his mourning and his loss intimating the dead, conflating himself with them, and succeeding in finding connections for his life ellipses.

Rehearsing adventures of the self, Dillon concentrates on partial unsolid features of his inexhaustible raw experiences of illness and loss. His efforts to yield flexibility to these experiences allow him to articulate attitudes situated in his body and to yield self-experience. Reflecting membra disjecta - mere unsorted particles of his life, particles appropriated for their latent forces, he gains access to a condition of a critical moment of creative powers. Made visible, they foreshadow a possibility of some other conglomerates, some other essays. Their goal is only occasional and provisional, precluding construction of a unified structure or fortification of some existing expertise.

\section{Bibliography}

Adorno, Theodor W. 1999. Notes to Literature. Translated by Shierry Weber Nicholsen. New York: Columbia University Press.

Auden, W. H. 1991. Collected Poems. Ed. Edward Mendelson. New York: Vintage International. Barthes, Roland 1993. Camera Lucida. Translated by Richard Howard. New York: Vintage.

De Quincey, Thomas 1922. Confessions of an English Opium-Eater. Berlin: Internationale Bibliothek. 
Detienne, Marcelle [\&] Jean-Pierre Vernant 1991. Cunning Intelligence in Greek Culture and Society, Chicago: University of Chicago Press.

Dillon, Brian 2006. "Anatomy of a Cloud". Sigrid Sandstrom. Grey Hope: The Persistence of Melancholy. Atopia Projects. 26-29.

- 2017. Essayism. London: Fritzcarraldo.

2018. In the Dark Room. London: Fritzcarraldo.

Dolmage, Jay 2009. "Metis, Mêtis, Mestiza, Medusa; Rhetorical Bodies across Rhetorical Traditions". Rhetoric Review 28, 1: 1-28.

Kauffmann, R. Lane 1989. “The Skewed Path: Essaying as Unmethodical Method". In: Alexander Butrym (ed.), Essays on the Essay: Redefining the Genre. Athens: University of Georgia Press.

Koestenbaum, Wayne 2019. Reviews. On-line: www.thisbooktravels.cm/books/essayists [19.04.2019].

Lausberg, Heinrich 2002. Retoryka literacka. Tłum. Albert Gorzkowski. Bydgoszcz: Homini.

Picard, Max 1952. The World of Silence. Chicago: Henry Regenery.

Stankowska, Agata 2001. "Elipsa - byt możliwy do zaktualizowania”. Teksty Drugie. 6/2001: 126132.

Suszek, Ewelina 2019. "Elipsa”. Ilustrowany stownik terminów literackich. Gdańsk: słowo/obraz terytoria.

Woolf, Virginia 2010. The Essays of Virginia Woolf. Vol. 5. Edited by Stuart N. Clarke. Boston: Houghton Mifflin Harcourt. 